\title{
THERMAL AND HUMIDITY CONDITIONS OVER A SALIENT LAND FORM AS EXEMPLIFIED BY A COASTAL SAND DUNE AT THE ŁEBA SANDBAR IN THE SŁOWIŃSKI NATIONAL PARK
}

\author{
Leszek Kolendowicz, Hanna ForycKa-ŁawniczaK
}

Institute of Physical Geography and Environmental Planning, Adam Mickiewicz University in Poznań, Poland

Manuscript received: January 30, 2013

Revised version: July 5, 2013

\begin{abstract}
Kolendowicz L., ForyCKa-ŁaWNicZaK H., 2013. Thermal and humidity conditions over a salient land form as exemplified by a coastal sand dune at the Łeba Sandbar in the Słowiński National Park. Quaestiones Geographicae 32(3), Bogucki Wydawnictwo Naukowe, Poznań, pp. 15-25. 2 tables, 10 figs. DOI 10.2478/quageo-2013-0026, ISSN 0137-477X.

AвSTRACT. In July 2011, measurements were taken of selected meteorological elements in the central part of the Łeba Sandbar in the Słowiński National Park. On the basis of the results of measurements performed at five points located on a salient land form in close proximity to the seashore, a thermal and humidity characteristics of this form were determined for a twenty-four hour period. The results of measurements obtained from an automatic weather station located in an open area, near the measurement points on the coastal sand dune, were used as information on the atmospheric conditions predominant in the standard area (flat area covered by grass). The research analysis was performed for the entire measurement period and for days with radiational weather. The authors also determined the dependence between air temperature and humidity values observed over the analysed land form and the values of weather elements measured over the standard area.
\end{abstract}

KEY wORDS: air temperature, relative humidity, correlation, regressive analysis, salient land form, Łeba Sandbar, Słowiński National Park

Address of the corresponding author: Leszek Kolendowicz, Institute of Physical Geography and Environmental Planning, Adam Mickiewicz University in Poznań, Dzięgielowa 27, 61-680 Poznań, Poland; e-mail: leszko@amu.edu.pl

\section{Introduction}

Out of the numerous research works devoted to the climatic conditions of the Słowiński National Park, one may single out among others the studies authored by Kolendowicz (2002) and Rabski (1987), which discuss thermal and humidity variability in selected types of ecosystems. Research has also been conducted into the twenty-four hour variability of wind speed and direction (Bogucki 1994, Tamulewicz 2001, Bednorz, Kolendowicz 2010a). A work concerning bioclimatic problems has been published by
Medzińska (1991), who presented the variability of the cooling power of air. Another analysis examined the synoptic determinants of strong precipitation during the summer period (Kolendowicz et al. 2004). Other works have been devoted to topoclimate types on the area of the Łeba Sandbar (Bednorz et al. 2001, Kolendowicz, Bednorz 2010a), and mesoclimatic issues (Rabski 1992). Microclimatic research has been conducted with the objective of determining the twenty-four hour variability of air temperature and humidity within a pine forest (Kolendowicz, Bednorz 2009, 2010), while soil temperature in various types of 
ecosystems has also been the subject of analyses (Bednorz, Kolendowicz 2010). In 2010, research was commenced - among others - into the microclimate of depressed land forms exemplified by the inter-sand dune depression located between coastal sand dunes in close proximity to the field station of the Unit of Climatology (Kolendowicz, Bednorz 2011).

The microclimate of salient forms differs from the microclimate of other land forms. Their fundamental feature is thermal differentiation between slopes of varying exposure, as well as between slopes and the apical section. During the day, the lowest temperature has been measured at the apical section, while during the night this section is the warmest. The greatest temperature values in the midday hours have been noted on slopes with a southern exposure, and the lowest on slopes with a northern exposure. At night, the thermal differentiation between slopes with a varying exposure is minor, and depends mainly on the features of the subsoil, such as its coverage (vegetation growth), humidity and thermal capacity (Geiger 1942, Molga 1986, Paszyński et al. 1999).

A detailed analysis of the impact of orography and vegetation growth on solar and thermal conditions was performed among others by Baranowski and Kuchcik (2001). When researching the local climate of the Polish Tatra Mountains and the Vitosha Massif in Bulgaria, they pointed to the considerable importance of both the intensity of solar radiation and wind speed for the thermal differentiation measured over areas of differing exposures, subsoil types and vegetation growth.

The significant impact of the inclination and exposure of slopes on the total solar radiation absorbed thereby has been pointed out, among others, by Stružek (1954), Kicińska et al. (2001), and Trepińska (2002). According to Stružek (1954), during a sunny day southern slopes with an inclination of, for example, $15^{\circ}$ receive $20 \%$ more energy, while slopes with an exposure - approximately 3\% solar energy less than a horizontal surface. This differentiation significantly impacts the spatial differentiation of thermal relations. This depends on the quantity of solar radiation absorbed by the active surface. In addition, the shaping of local thermal relations is significantly impacted by the type of active surface and the frequency of sunny and cloudy days (Paszyński 1999, Olecki 2000, Obrębska-Starklowa 2001). One may single out a number of works that have been devoted to the issue of the influence of solar radiation on soil temperature and attempted to achieve a model presentation of the dependences between soil thermal conditions and the intensity of solar radiation, air temperature and wind speed for areas with varied vegetation growth (Bednarek 1966, Bednorz, Kolendowicz 2010b, Keryn et al. 2004, Mungai et al., 1998).

\section{Objective of the study and research methods}

The objective of the study was to examine twenty-four hour thermal and humidity differentiation over a salient land form using the example of a coastal sand dune, and to make an attempt at a model presentation of the dependence between air temperature and humidity over specific fragments of the sand dune (slopes with varying exposure and the apical section) and the values of weather elements characterising the air above a horizontal surface. The study is a continuation of research into the microclimates of different types of ecosystems, conducted at the Łeba Sandbar by scholars from the Unit of Climatology of the Institute of Physical Geography and Environmental Planning of Adam Mickiewicz University.

In the course of field measurements performed from 18th to 24th July 2011, five HOBO air temperature data loggers were used, which were placed in radiation shields on slopes with a northern, eastern, southern and western exposure, and on the apex of the land form, at a height of $50 \mathrm{~cm}$ above ground level (Fig. 1).

Measurements of air temperature and humidity above the analysed land form were performed over 7 days at one-hour intervals. During 3 out of these 7 days (19th, 22nd and 24th July) the weather was radiational, characterised by slight cloudiness and zero or low-wind speed. Under these synoptic conditions, the streams of energy reaching and escaping from the active surface adopt the greatest values. In consequence, the thermal 


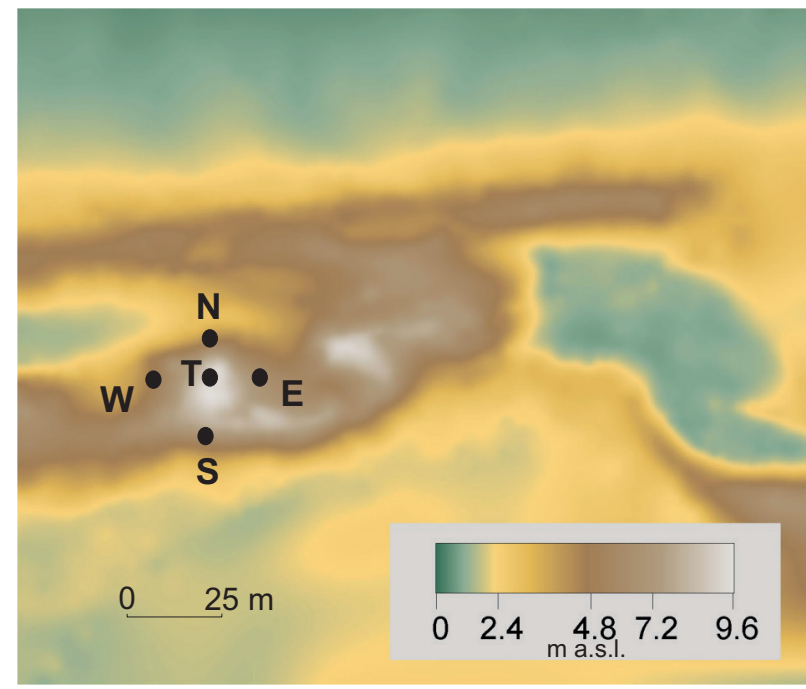

Fig. 1. Hypsometric model of the research area with the location of measurement points

$\mathrm{T}$ - apex of the sand dune, $\mathrm{W}$ - western slope, $\mathrm{N}$ - northern slope, E - eastern slope, $\mathrm{S}$ - southern slope

differentiation of slopes with varying exposures is the greatest (Paszyński et al. 1999).

When describing the thermal and humidity conditions predominant during a twenty-four hour period above the land form in question, the researchers averaged the air temperature and relative humidity values for individual measurement dates, both for the entire measurement period and for days with radiational weather. The results obtained have been presented on charts covering the entire measurement period and days with radiational weather. In addition, the research period has been described in terms of the progress of the values of total radiation intensity, the radiation balance, as well as air temperature and humidity and wind speed measured by an automatic MAWS 201 station located in an open area near the analysed coastal sand dune.

Further on in the study, the authors have calculated the coefficient of correlation between temperature and relative humidity values measured above the coastal sand dune and selected meteorological elements from above the horizontal surface. The analysis takes into consideration the value of the radiational balance, air temperature, and relative air humidity. Subsequently, using simple regressive models, the researchers examined the relation between air temperature and relative air humidity over the sand dune and the aforementioned elements from above the horizontal surface.

\section{Results of research}

The analysis of the twenty-four hour changes of air temperature and humidity above the salient land form in question has been preceded by a description of the weather conditions predominant over a flat area located in close proximity (approximately $200 \mathrm{~m}$ ) to the sand dune. An automatic MAWS 201 weather station was located on this area, and the results of its measurements constitute the backdrop - a reference point - for the results of research into the coastal sand dune. Values obtained from the MAWS 201 station indicate that the examined period was characterised by average air temperature values. Researchers noted the occurrence of 2 hot days with a maximum temperature in excess of $25^{\circ} \mathrm{C}$. Very hot days with a maximum temperature above $30^{\circ} \mathrm{C}$ did not occur. The maximum value of temperature was $25.9^{\circ} \mathrm{C}$ on 22 nd July at approx. 14.00 , and the minimal $12.5^{\circ} \mathrm{C}$ on 24 th July at approximately 03.00. Relative humidity ranged from $36.4 \%$ on 24 th July at approximately 17.00 to more than $95 \%$ on 21 st July in the early morning hours, showing a very clear and typical relationship with the progress of air temperature (Fig. 2).

The intensity of total radiation during the researched period was somewhat variable. On two days (19th and 24th July) it exceeded the value of $800 \mathrm{~W} / \mathrm{m}^{2}$ in the midday hours. During the remainder of the researched period it attained lower values, with the minimum value during the day totalling only $170 \mathrm{~W} / \mathrm{m}^{2}$ (23rd July). The radiation balance attained relatively high values during the day on days with a large intensity of total radiation. The value of the balance during this time exceeded $550 \mathrm{~W} / \mathrm{m}^{2}$. During a night with radiational weather, the values of the balance were frequently lower than $-50 \mathrm{~W} / \mathrm{m}^{2}$. The lowest balance value was observed during the clear night of 24 th July, at 0.00 , totalling $-70 \mathrm{~W} /$ $\mathrm{m}^{2}$ (Fig. 3).

The wind speed during the majority of days of the analysed period was not high, and did not exceed $5 \mathrm{~m} / \mathrm{s}$. In the majority of the analysed days, the wind speed ranged from $0 \mathrm{~m} / \mathrm{s}$ (during short periods of the night hours of selected days) to 5 $\mathrm{m} / \mathrm{s}$ (during the midday hours of 20th July 2011). An analysis of the researched element points 


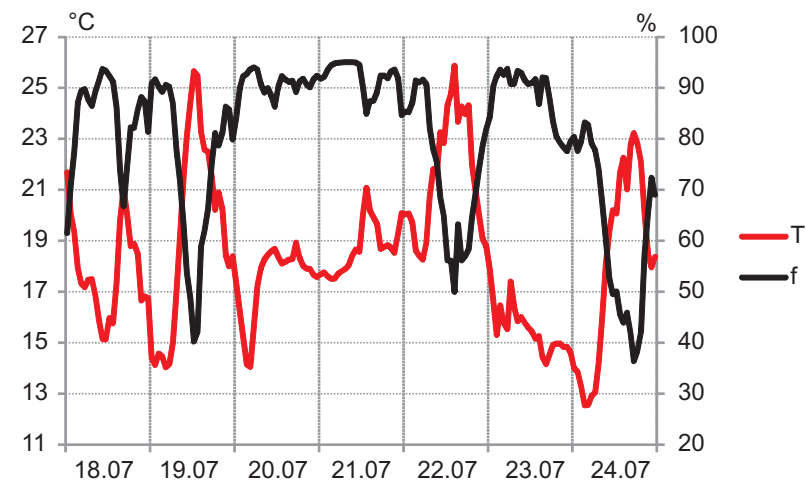

Fig. 2. The progress of the values of air temperature $(\mathrm{T})$ and air humidity (f) during the period from 18th to 24th July 2011, measured over the horizontal surface. Łeba Sandbar

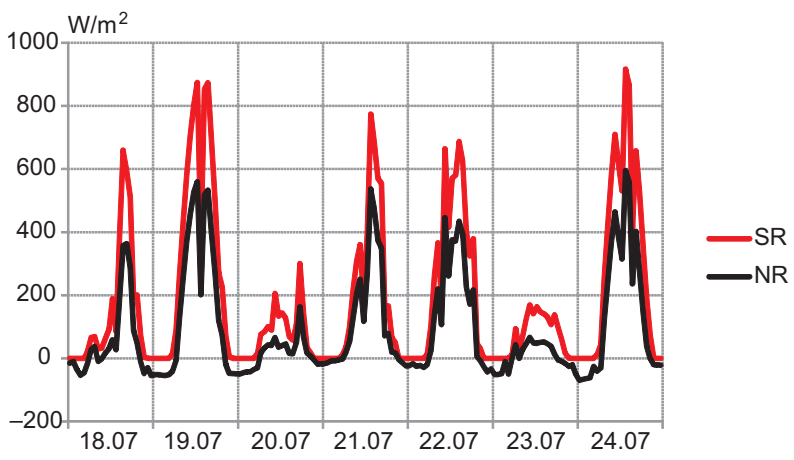

Fig. 3. The progress of the values of total radiation intensity (SR) and of the short- and radiation balance (NR) during the period from 18th to 24th July 2011, measured over the horizontal surface. Łeba Sandbar

to the periodicity of occurrence of higher wind speeds during the daytime (Fig. 4).

The progress of air temperature values for an average twenty-four hour period from the researched period for measurement points located on the coastal sand dune and on a flat surface for all days of the researched period has been

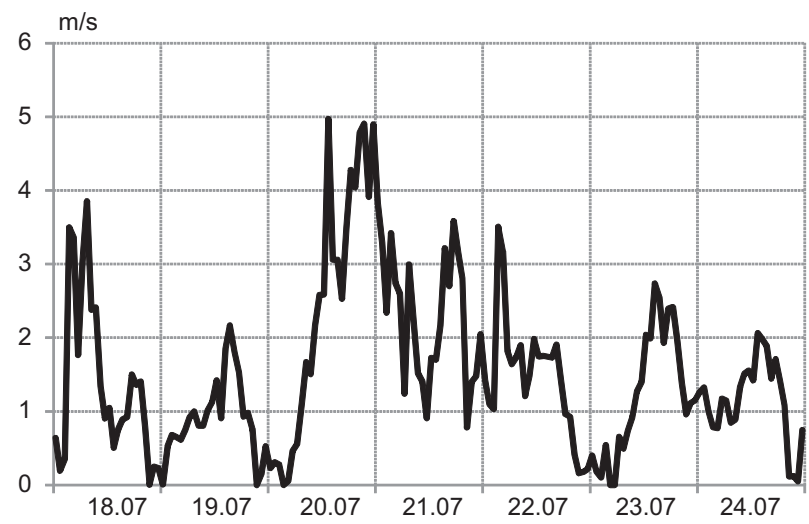

Fig. 4. Wind speed during the period from 05.07.2010 to 06.08.2010, measured 4 meters above the horizontal surface. Łeba Sandbar presented in Figure 5, while for days with radiational weather - in Figure 6. The progress of temperature values at all stations, both for an average twenty-four period from the entire research period and for an average twenty-four hour period with radiational weather, is similar. The lowest values occur at 04.00 (from $15.7^{\circ} \mathrm{C}$ to $16.4^{\circ} \mathrm{C}$ ), and the highest at 14.00 (from $20.0^{\circ} \mathrm{C}$ to $20.8^{\circ} \mathrm{C}$ on an average day, and from $22.4^{\circ} \mathrm{C}$ to $23.9^{\circ} \mathrm{C}$ on an average day with radiational weather). From 05.00, the temperature grows rapidly (up to 14.00) until it reaches the highest values. During this time, thermal differentiation gradually develops between individual measurement stations. While differentiation is non-existent at approximately 06.00, the layer of air suspended over the slope with a southern and western exposure begins to get steadily warmer. The values of temperature above these slopes are nearly the same as over the flat surface (MAWS 201 station). At the remaining stations it is somewhat cooler, whereas the lowest temperature values are observed at the apex of the sand dune. From 10.00, the differentiation of measured values becomes clearer than before, while after 13.00 the largest differences are observed between the analysed measurement points, totalling up to $0.2^{\circ} \mathrm{C}$ on an average day and $1.2^{\circ} \mathrm{C}$ on an average day with radiational weather. From this moment on, the warmest air is situated over the slope with a southern and western exposure, while the temperature measured above the flat surface becomes distinctly lower than that above the said slopes. Between 13.00 and 18.00 , the differentiation of temperature between measurement stations is greatest for the entire twenty-four hour period, with differences between extreme values for the warmest southern slope and the coolest point, i.e. the apex of the sand dune, totalling approximately $1^{\circ} \mathrm{C}$. During this time, researchers also observed the simultaneous gradual fall in temperature values at all measurement points. In this period, the temperature above the flat surface adopts intermediate values between those observed over the southern and western slope, and the remaining measurement points. After 18.00, the temperature at all stations falls considerably faster, being reminiscent of the morning rise, while the thermal differentiation between these values de- 
creases rapidly. It was noted that from 20.00 the lowest temperature occurs above the flat surface (MAWS 201 station), and this continues until 06.00, while from 22.00 until 06.00 the apex of the sand dune is warmest.

When comparing both analysed charts, one may observe that during the period of occurrence of radiational weather the values of air temperature from 08.00 to 23.00 are considerably higher (and lower during the night) in comparison with an average twenty-four hour period for the entire research period.

Analyses of the progress of air relative humidity values at all measurement stations, both for an average twenty-four period from the entire research period and an average twenty-four period with radiational weather, are characterised by considerable similarity (Fig. 7 and 8).

Between 03.00 and 06.00, air located above the slope with a southern and eastern exposure is characterised by the greatest relative humidity. The maximum humidity value occurs at 05.00 , and totals 95\%. From 06.00, relative humidity falls evenly at all stations (with the exception of the flat surface outside the analysed land form), and values at all measurement points are very similar. The greatest differences between analysed measurement points occur from 12.00 to 19.00. The lowest relative humidity during an

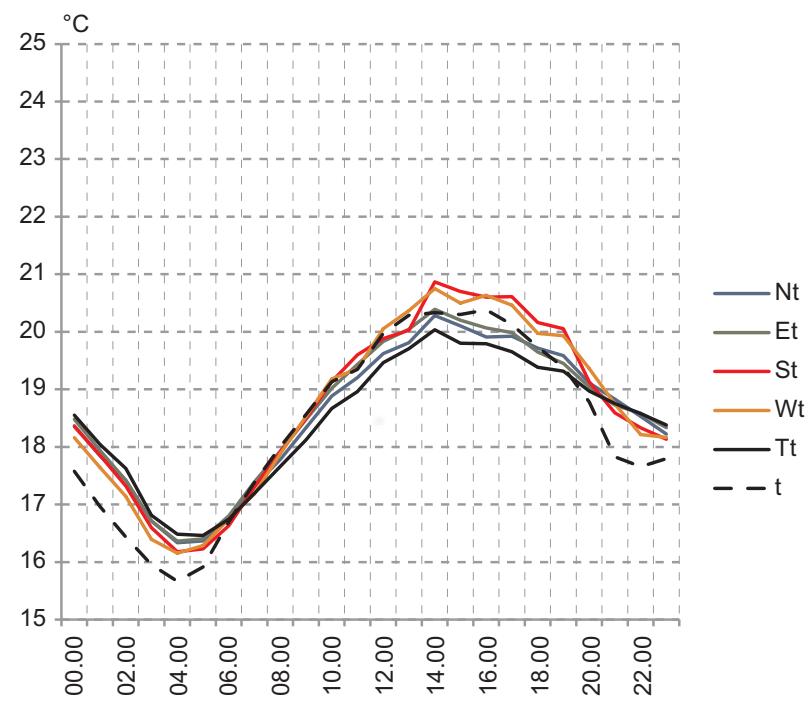

Fig. 5. The progress of air temperature values during the twenty-four hour period at measurement points located on the coastal sand dune

$\mathrm{Nt}$ - northern slope, Et - eastern slope, St - southern slope, Wt western slope, $\mathrm{Tt}$ - apex of the sand dune, and measured above the horizontal surface - t. Łeba Sandbar 18-24.07.2011 average twenty-four hours period occurs from 14.00 to 15.00 , attaining a minimum of approximately $75 \%$ over the slope with a southern and western exposure. In turn, the lowest air humidity for days with radiational weather occurs between 12.00 and 14.00, during which time it falls to $62 \%$ on the slope with a southern exposure (at 14.00 ) and to $64 \%$ on the slope with a western exposure. From 16.00, air humidity at all measurement points starts to rise evenly until 21.00, attaining approximately $85 \%$.

When comparing data from observation points located on the flat area and on the coastal sand dune, the authors observed that for nearly the entire twenty-four hour period the value of relative humidity of air above the flat area is clearly lower than that of air over stations situated on the sand dune. Selected night hours are the periods with the lowest differentiation.

Further on in the study we made an attempt at explaining the dependence of the temperature and humidity of air above specific sand dune fragments on the values of meteorological elements typical of air over the horizontal surface.

When researching the interdependence between the temperature and relative humidity of air over the sand dune and the values of the radiation balance and the temperature and relative humidity of air over the horizontal surface, the au-

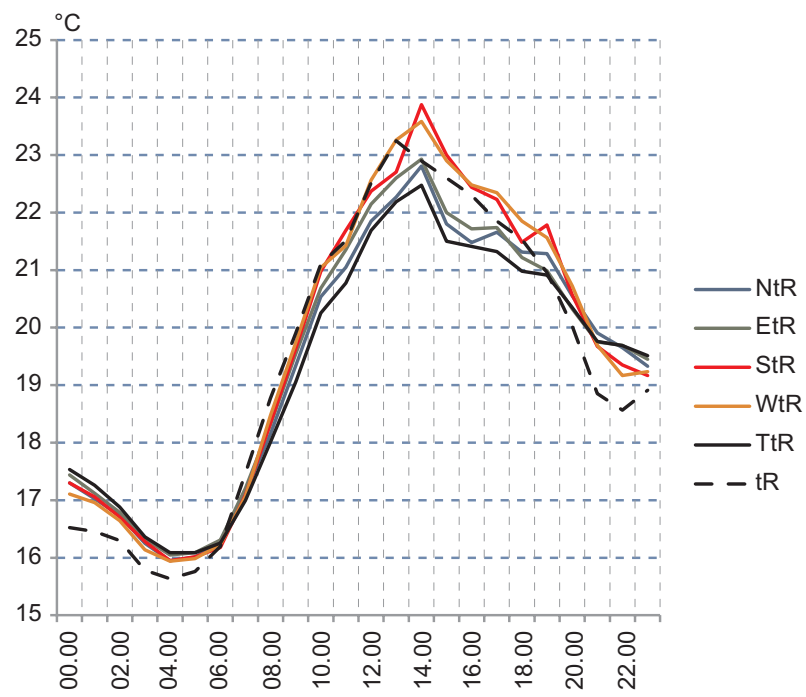

Fig. 6. The progress of air temperature values during the twenty-four hour period at measurement points located on the coastal sand dune on days with radiational weather $\mathrm{NtR}$ - northern slope, EtR - eastern slope, StR - southern slope, WtR - western slope, TtR - apex of the sand dune, and measured above the horizontal surface - tR. Łeba Sandbar 18-24.07.2011 


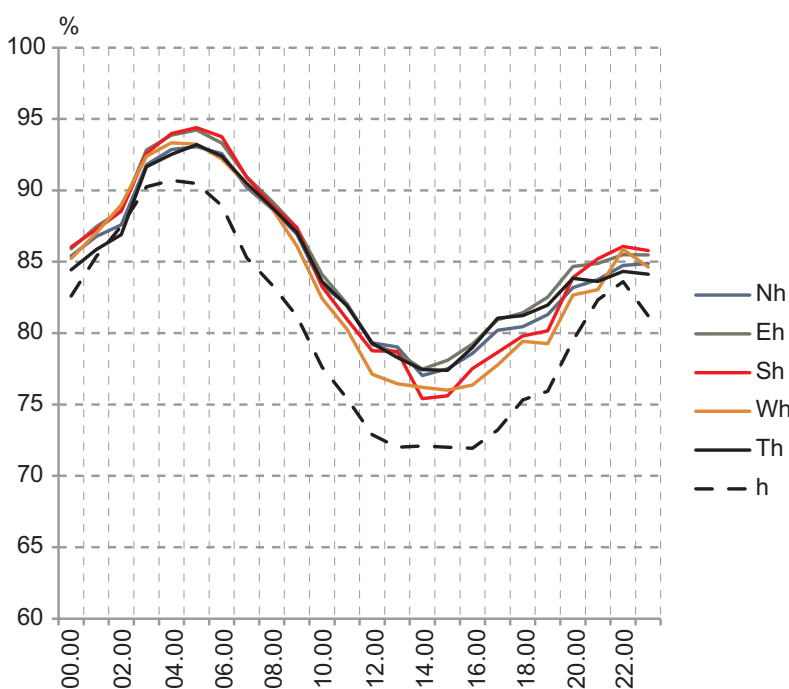

Fig. 7. The fluctuation of air humidity during the twenty-four hour period at measurement points located on the coastal sand dune

$\mathrm{Nh}$ - northern slope, Eh - eastern slope, Sh - southern slope, Wh western slope, Th - apex of the sand dune, and measured above the horizontal surface - h. Łeba Sandbar 18-24.07.2011

thors calculated Pearson's correlation coefficients for the fluctuations of the abovementioned meteorological elements in the researched period. Due to the relatively short research period, calculations have taken into consideration the entire measurement period, excluding only days with radiational weather from the analysis. The results obtained have been presented in Tables 1 and 2 .

The values of correlation coefficients thus obtained both for the temperature and relative humidity of air over the sand dune and the horizontal surface are very high and differ only slightly from each other. The strongest correlation occurs for the slope with a western exposure, while the weakest - for the apex of the sand dune.

Table 1. The value of Pearson's correlation coefficients for the fluctuations of air temperature above the sand dune area $(\mathrm{N}$ - northern slope, $\mathrm{E}$ - eastern slope, $\mathrm{S}$ - southern slope, $\mathrm{W}$ - western slope, $\mathrm{T}$ - apex of the sand dune), and the fluctuations of temperature $t$ and the value of the radiation balance NR over the horizontal surface. The calculated coefficients are statistically significant for a level $p=0.05$. Łeba Sandbar 18-24.07.2011

\begin{tabular}{|c|c|c|}
\hline & $\mathbf{t}$ & NR \\
\hline $\mathrm{N}$ & 0.961824 & 0.709913 \\
\hline $\mathrm{E}$ & 0.970432 & 0.744756 \\
\hline $\mathrm{S}$ & 0.973233 & 0.753814 \\
\hline $\mathrm{W}$ & 0.982199 & 0.762484 \\
\hline $\mathrm{T}$ & 0.938476 & 0.670133 \\
\hline
\end{tabular}

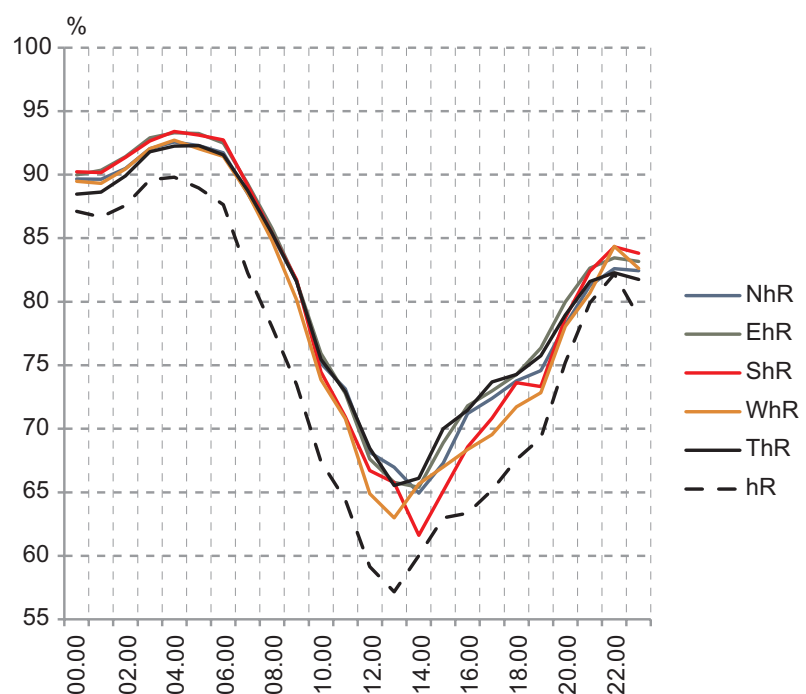

Fig. 8. The fluctuation of air humidity during the twenty-four hour period at measurement points located on the coastal sand dune on days with radiational weather $\mathrm{NhR}$ - northern slope, EhR - eastern slope, ShR - southern slope, WhR - western slope, ThR - apex of the sand dune, and measured above the horizontal surface - hR. Łeba Sandbar 18-24.07.2011

When examining the interdependence between the temperature and humidity of air above the sand dune and the radiation balance over the horizontal area, the results of correlation obtained were the weakest, although its coefficients attain values of approximately 0.7 for air temperature and approximately - 0.7 for relative air humidity. Similarly to the results of the previous analysis, the strongest correlation was observed for the western slope (temperature) and the southern and western slopes (relative humidity), while the weakest - for the apex of the sand dune.

During the next stage of research, the authors analysed the impact of the value of the radiation balance on temperature values measured above

Table 2. The value of Pearson's correlation coefficients for the fluctuations of air humidity above the sand dune area $(\mathrm{N}$ - northern slope, $\mathrm{E}$ - eastern slope, $\mathrm{S}$ - southern slope, $\mathrm{W}$ - western slope, $\mathrm{T}$ - apex of the sand dune), and the fluctuations of humidity $h$ and the value of the radiation balance NR over the horizontal surface. The calculated coefficients are statistically significant for a level $p=0.05$. Łeba Sandbar 18-24.07.2011

\begin{tabular}{|c|c|c|}
\hline & h & NR \\
\hline N & 0.965345 & -0.707840 \\
\hline E & 0.971105 & -0.734705 \\
\hline S & 0.975890 & -0.747607 \\
\hline W & 0.983660 & -0.740611 \\
\hline T & 0.948571 & -0.685412 \\
\hline
\end{tabular}



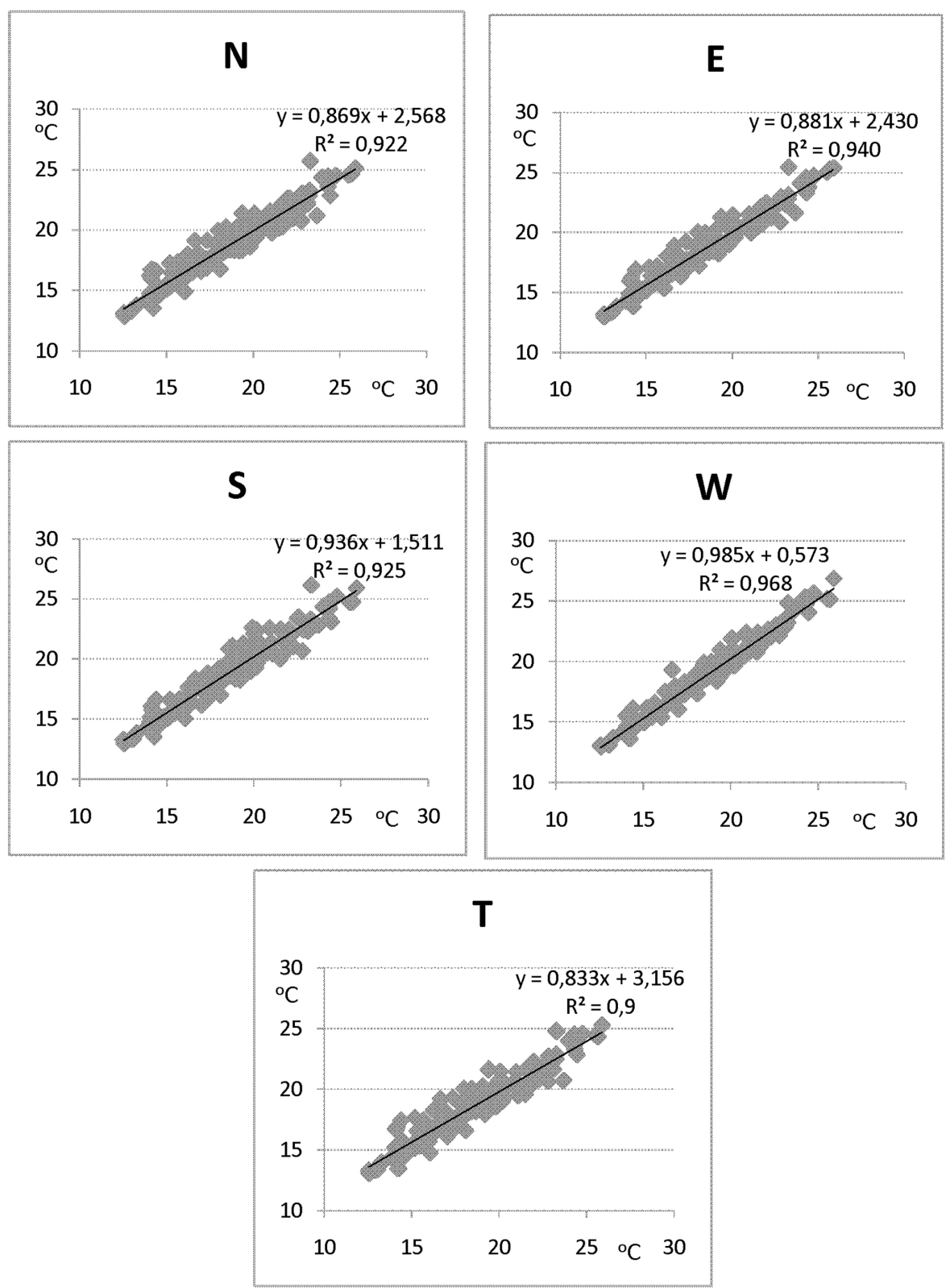

Fig. 9. Dependence of air temperature values above the sand dune area $(\mathrm{N}$ - northern slope, $\mathrm{E}$ - eastern slope, $\mathrm{S}$ - southern slope, $\mathrm{W}$ - western slope, $\mathrm{T}$ - apex of the sand dune) on the value of temperature over the horizontal surface. Łeba Sandbar $18-24.07 .2011$

the coastal sand dune. The researched dependences were linear, and the models constructed explained the values of temperature above the sand dune in approximately $30 \%$. This indicated that the temperature above the western and eastern slopes was most strongly connected with the value of the radiation balance on the horizontal surface. The weakest relations concerned the apex of the sand dune. The differences between the results of model research for slopes with varying exposures and the apex of the sand dune attained a value of a few per cent. Very similar results were obtained for relative air humidity.

Due to the weak results of the aforementioned model research, the authors performed an analysis of the dependence of values of air temperature above the sand dune on temperature values measured over the flat area. Because of the short measurement period (7 days) and the relatively small volume of data thus obtained, model research was conducted for the entire measurement series, without a separate analysis for days with radiational weather. 

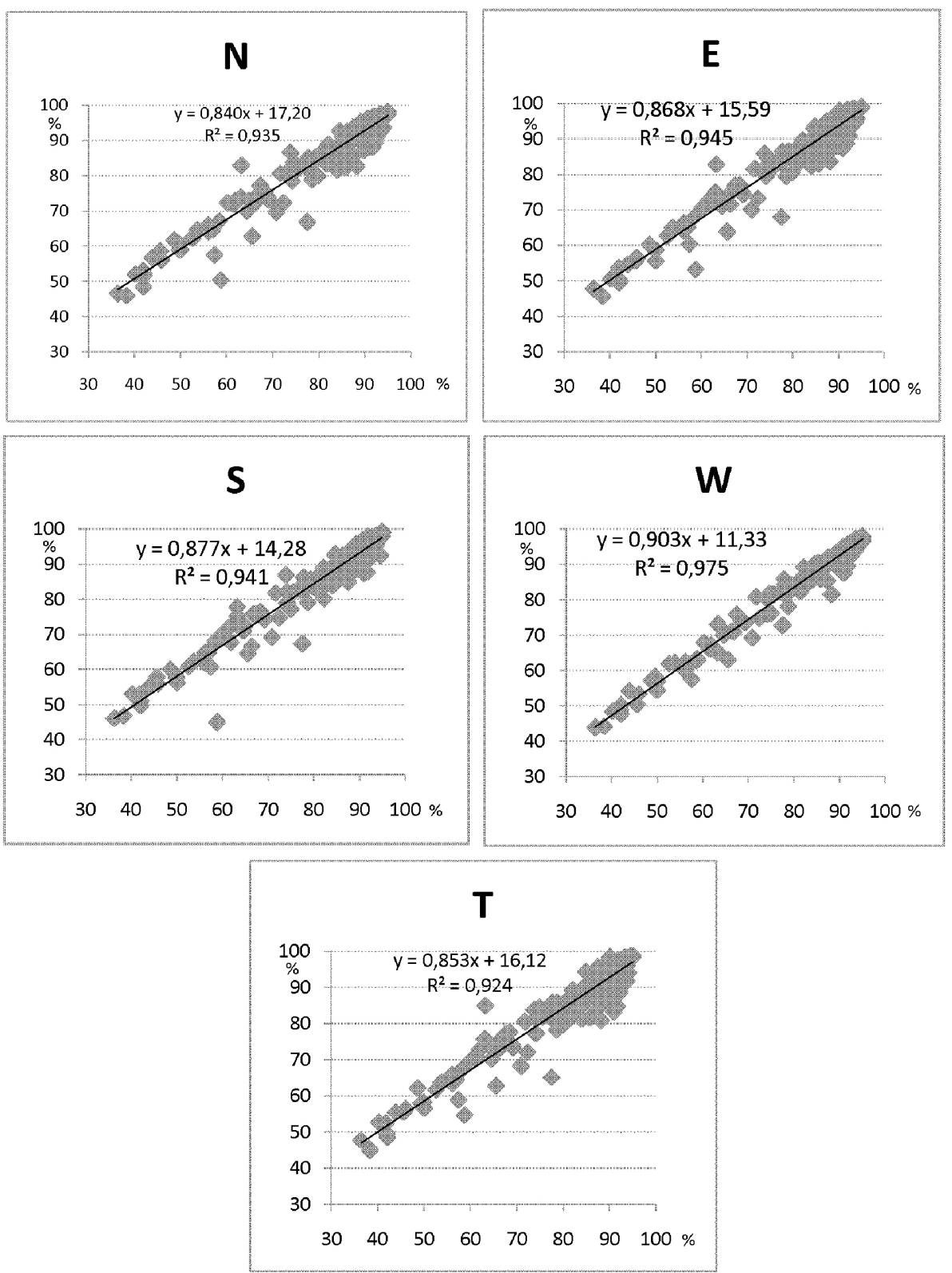

Fig. 10. Dependence of air humidity values above the sand dune area ( $\mathrm{N}$ - northern slope, $\mathrm{E}$ - eastern slope, $\mathrm{S}$ - southern slope, $\mathrm{W}$ - western slope, $\mathrm{T}$ - apex of the sand dune) on the value of humidity over the horizontal surface. Łeba Sandbar 18-24.07.2011

The regression coefficients obtained $\left(R^{2}\right)$ for simple regression equations are high (values greater than or equal to 0.9) and statistically significant at a level of $p=0.05$. The strongest linear dependence on temperature above the standard area concerns the air temperature measured above the western slope of the sand dune. In this instance, the determination coefficient for the regression equation totals 0.968 . In turn, the weakest dependence was observed for the temperature of air above the apex of the analysed land form, for which the regression equation explains temperature variability in $90 \%$. Regression coefficients obtained for remaining slopes fall within the values previously described (Fig. 9).

During the next stage of the study, the researchers analysed the dependence of the value of the relative humidity of air above the sand dune on humidity observed over the flat area. The results attained are characterised by considerable similarity to the relationships involving air temperature, described previously. The strongest linear dependence occurs for the humidity of air situated above the slope with a western expo- 
sure. In this instance, the determination coefficient $\left(\mathrm{R}^{2}\right)$ calculated for the regression equation totals 0.975 . The humidity observed over the flat surface exerts the weakest impact on relative humidity observed over the apex of the sand dune. In this case, the regression coefficient $\left(\mathrm{R}^{2}\right)$ totals 0.924 . For the remaining slopes of the sand dune, the values of the determination coefficient attained are intermediate. The results obtained are statistically significant for a level $p=0.05$.

\section{Conclusions and a discussion of results}

The objective of the study was to characterise the twenty-four hour fluctuations of the values of air temperature and humidity over a salient land form (coastal sand dune) located in the central part of the Łeba Sandbar on the area of the Słowiński National Park. Both the values of temperature and relative humidity are characterised by very distinct fluctuations during the twenty-four hour period.

The lowest air temperature values - irrespective of the location over the surface of the sand dune and the type of weather - occur at 04.00. From 05.00, the temperature grows rapidly, attaining the highest value of the entire twenty-four hour period at approximately 14.00. At the same time, the layer of air suspended over the slope with a southern and western exposure begins to get steadily warmer than other air layers. Until 13.00, the values of temperature above the aforementioned slopes are nearly identical to those over the flat area, while from 13.00 until 21.00 the temperature above these slopes is the highest from amongst all measurement points. Between 13.00 and 18.00, thermal differentiation between measurement points is greatest for the entire twenty-four hour period. After 18.00, the temperature at all stations falls rapidly, while thermal differentiation over the area of the sand dune decreases. In addition, it should be observed that from 06.00 to 20.00 , the coolest air is suspended over the apex of the sand dune, while from 20.00 to 06.00 the lowest temperature was observed over the flat surface, and the greatest over the apex of the analysed land form. A greater differentiation of air temperature values, in particular during the midday hours and in the morning, has been noted during radiational weather. During such days, the daily air amplitude is also greater.

What is more, the progress of values of relative humidity during the twenty-four hour period at all measurement stations, irrespective of the type of weather, is characterised by considerable similarity. Between 03.00 and 06.00, air located above the slope with a southern and eastern exposure is characterised by the greatest relative humidity. The maximum humidity value occurs at 05.00 , and totals $95 \%$. From 6.00, relative humidity falls evenly, with no significant difference between the value of this parameter at individual stations. The lowest relative humidity occurs from 14.00 to 15.00, attaining a minimum over the slope with a southern and western exposure. The greatest differences between analysed measurement points occur from 12.00 to 19.00. From 16.00, air humidity at all measurement points starts to rise evenly, and continues to rise until 22.00, where after it falls slightly until 01.00 and subsequently rises until 03.00-04.00. Similarly to the progress of temperature, greater daily amplitudes and a greater differentiation between measurement stations in the night and midday hours occur during radiational weather.

Research results obtained for the twenty-four hour fluctuations of air temperature and relative humidity over the salient land form and the differences between them, contingent upon the exposure of slopes, coincide with the results attained by other authors (Geiger 1942, Stružek 1954, Molga 1971, Olecki 2000, Bokwa 2001, Obrębska-Starklowa 2001).

However, as opposed to works devoted to an analysis of the impact of the intensity of solar radiation, air temperature and wind speed on soil temperature (Bednarek 1966, Mungai et al. 1998, Keryn et al. 2004, Bednorz, Kolendowicz $2010 \mathrm{~b}$ ), the results obtained for the impact of the radiation balance at the horizontal surface on the temperature over the area of the sand dune were rather unsatisfactory. The regression models obtained helped explain the said relation in no more than $30 \%$. Results were improved only slightly (by a few per cent) by taking wind speed into consideration. In turn, research into the dependence of temperature and relative humidity over the sand dune on temperature and humidity 
over the horizontal surface gave decidedly better results. The dependence between the aforementioned elements is linear, and the models attained explain the relation in more than $90 \%$. Although the differences between the results of research concerning both temperature and humidity over slopes and the apex are slight, totalling no more than a few per cent, one may point to the strongest dependences between researched elements above the horizontal surface and the slope with a western and eastern exposure. The weakest results were obtained for the apex of the sand dune.

Results attained for the strongest and weakest relationships of air temperature over the sand dune coincide with the results of the model research - previously conducted in the present study - into the dependence of temperature and the value of the radiation balance, although they differ considerably as regards the values of regression coefficients.

The results obtained for the model research confirm the existing state of knowledge concerning the impact of the topographic profile and land exposure on the twenty-four hour progress of the temperature and relative humidity of air. The apexes of acclivities, beds of closed hollows, and slopes with a northern and southern exposure differ most considerably in terms of the twenty-four hour fluctuations of air temperature from values typical of the horizontal surface; in the main, this is caused by the quantity of solar radiation energy absorbed during the day and the downward flow of cool air along slopes in the night. These connections translate directly into relations concerning the relative humidity of air, for changes in this index are connected primarily with changes in the value of air temperature (Geiger 1942, Molga 1971, Paszyński 1999).

\section{References}

Baranowski J., Kuchcik M., 2001. Wybrane aspekty warunków termicznych Tatr oraz masywu Witoszy w Bułgarii. In: M. Kuchcik (ed.), Wspótczesne badania topoklimatyczne. Dokumentacja Geograficzna IGiPZ PAN. 23: 9-17.

Bednarek A., 1966. O wpływie temperatury powietrza na kształtowanie temperatury gleby w warunkach ograniczonego dopływu energii promieniowania Słońca. Przeglad Geofizyczny 11(4): 251-260.
Bednorz E., Kolendowicz L., 2010a. Lokalne zróżnicowanie parametrów wiatru na Mierzei Łebskiej (Słowiński Park Narodowy). Badania Fizjograficzne R1 - seria A - Geografia Fizyczna, A61: 119-127.

Bednorz E., Kolendowicz L., 2010b. Daily course of the soil temperature in summer in chosen ecosystems of Słowiński National Park. Quaestiones Geographicae 29(1): 5-12.

Bednorz E., Kolendowicz L., Szyga-Pluta K., 2001. Typy topoklimatu Słowińskiego Parku Narodowego. Dokumentacja Geograficzna. 23: 19-32.

Bogucki J., 1994. Dobowa zmienność kierunku wiatru na Mierzei Łebskiej. Badania Fizjograficzne nad Polska Zachodnia ser. A - Geografia Fizyczna, 45: 5-23.

Bokwa A., 2001. Wpływ cyrkulacji atmosferycznej na dzienny przebieg pionowych gradientów termicznych $\mathrm{w}$ przygruntowej warstwie powietrza. Dokumentacja Geograficzna 23: 33-40.

Geiger R., 1942. Das Klima der Bodennahen Luftschicht. Die Wissenschaft BD78, Braunschweig.

Keryn I.P., Polglase P.J., Smethurst P.J., O'Connel A.M., Caryle C.J., Khana P.K., 2004. Soil temperature under forests: a simple model for predicting soil temperature under a range of forest types. Agricultural and Forest Meteorology 121: 167-182.

Kicińska B., Olszewski K., Żmudzka E., 2001. Uwagi o wykorzystaniu klasyfikacji J. Paszyńskiego do kartowania topoklimatycznego ( $\mathrm{z}$ doświadczeń Zakładu Klimatologii Uniwersytetu Warszawskiego). Dokumentacja Geograficzna 23: 143-151.

Kolendowicz L., 2002. Zróżnicowanie temperatury, wilgotności względnej oraz wielkości ochładzającej powietrza w Słowińskim Parku Narodowym. Badania Fizjograficzne nad Polska Zachodnia ser. A - Geografia Fizyczna, 53: 83-93.

Kolendowicz L., Bednorz E., 2009. Microclimatic conditions within a pine forest in August 2008 on the Łeba Sandbar (Słowiński National Park). Questiones Geographicae 28A/1: 32-39.

Kolendowicz L., Bednorz E., 2010a. Topoclimatic differentiation on the area of the Słowiński National Park. Quaestiones Geographicae 29(1): 5-12.

Kolendowicz L., Bednorz E., 2010b. Warunki mikroklimatyczne we wnętrzu boru sosnowego na Mierzei Łebskiej. Badania Fizjograficzne R1 - ser. A - Geografia Fizyczna, A61: 157-168.

Kolendowicz L., Bednorz E., 2011. Charakterystyka termiczna wklęsłej formy terenowej w okresie letnim 2010 r. na przykładzie zagłębienia międzywydmowego $\mathrm{w}$ Słowińskim Parku Narodowym. Badania Fizjograficzne R2 - ser. A - Geografia Fizyczna, A62: 69-86.

Kolendowicz L., Bednorz E., Szyga-Pluta K., 2004. Analysis of chosen cases of high daily rainfall at the local station of Climatology Department Adam Mickiewicz University in Poznań in Słowiński National Park. Questiones Geographicae 23: 49-54.

Medzińska M., 1991. Charakterystyka wielkości ochładzającej powietrza w profilu Mierzei Łebskiej w okresie letnim 1988. Badania Fizjograficzne nad Polska Zachodnia ser. A - Geografia Fizyczna, 37: 73-89.

Molga M., 1986. Meteorologia rolnicza. PWRiL, Warszawa.

Mungai D.N., Stigter C.J., Coulson C.L., Ng'ang'a J.K., 1998. Simply obtained global radiation, soil temperature and soil moisture in an alley cropping in semi-arid Kenya. Theoretical and Applied Climatology 65: 63-78. 
Obrębska-Starklowa B., 2001. Wpływ zmian użytkowania ziemi w dolinie Raby na warunki termiczne zbiorowiska leśnego. Dokumentacja Geograficzna 23: 59-74.

Olecki Z., 2000. Differentiation of the solar conditions in the Carpathian Foothills during 1971-1997. In: Topoclimatic and geoecological changes in the Wieliczka foothills in the surroundings of the Dobczyce reservoir. MS

Paszyński J., Miara K., Skoczek J., 1999. Wymiana energii między atmosferą a podłożem jako podstawa kartowania topoklimatycznego. Dokumentacja Geograficzna 14.

Rabski K., 1987. Wstępna charakterystyka termiczno-wilgotnościowa Mierzei Łebskiej. Badania Fizjograficzne nad Polska Zachodnia ser. A - Geografia Fizyczna, 42: 191-205.
Rabski K., 1992. Mezoklimatyczne tło obszaru Słowińskiego Parku Narodowego. Parki Narodowe i Rezerwaty Przyrody. 11(1).

Strużka V., 1954. Metody badań bioklimatycznych. PZLG, 3: 170-195.

Tamulewicz J., 2001. Prędkość wiatru w sezonie letnim w Słowińskim Parku Narodowym w obrębie Mierzei Łebskiej. Badania Fizjograficzne nad Polska Zachodnia ser. A - Geografia Fizyczna, 52: 149-159.

Trepińska J., 2002. Górskie klimaty. Monografie 20, UJ Kraków, 202 pp. 